\title{
Duas ditaduras e uma só liberdade: Mário Pedrosa, o fascismo colonial e o bonapartismo militar
}

\author{
Everaldo de Oliveira Andrade ${ }^{1}$ \\ Recebido em setembro de 2020 \\ Aceito em dezembro de 2020
}

\section{RESUMO}

Este artigo analisa a produção política e intelectual de Mário Pedrosa tendo como referência sua atuação no período da década de 1930 que desembocou na ditadura varguista (1937-1945|) e depois no período da ditadura militar iniciada em 1964. Busca-se refletir sobre a possível originalidade das suas abordagens, em particular através do uso de conceitos como bonapartismo e desenvolvimento desigual e combinado no estudo do autoritarismo e da perenidade de traços e práticas fascistas nos governos brasileiros nos dois períodos. São utilizadas como fontes documentais a coleção de jornais O Homem Livre (1933-1934) e textos e obras do próprio autor produzidas no período em análise.

Palavras-chave: Mário Pedrosa; fascismo brasileiro; ditaduras no Brasil; bonapartismo; desenvolvimento desigual e combinado.

\section{Two dictatorship and only one freedom: Mário Pedrosa, the colonial fascismo and the military bonapartism}

\begin{abstract}
This article analyzes the political and intellectual production of Mário Pedrosa having as reference his performance in the period of the 1930s that ended in the Vargas dictatorship (1937-1945) and then in the period of the military dictatorship that began in 1964. It seeks to reflect on the possible originality of their approaches, in particular through the use of concepts such as Bonapartism and uneven and combined development in the study of authoritarianism and the continuity of fascist traits and practices of Brazilian governments in both periods. The collection of newspapers O Homem Livre (1933-1934) and texts and works by the author himself produced in the period under analysis are used as documentary sources.
\end{abstract}

Keywords: Mário Pedrosa; Brazilian fascism; dictatorships in Brazil; bonapartism; uneven and combined development.

\section{Introdução}

Mário Pedrosa viveu e atuou politicamente em períodos de avanços autoritários que desembocaram em governos antidemocráticos: a ditadura varguista do Estado Novo e a ditadura militar pós 1964. Em ambas foi obrigado a se exilar por conta de perseguições

\footnotetext{
${ }^{1}$ Everaldo de Oliveira Andrade, professor no departamento de História da FFLCH - USP
} 
políticas. Sua atuação na década de 1930 foi marcada pela ação contra o avanço do fascismo brasileiro e a implantação da ditadura varguista. Décadas depois, e em contexto bem diferente, seguiu atuando como homem de ação e de palavras buscando derrotar a nova ditadura de 1964 e suas redes de apoios autoritárias e fascistas. A comparação destes dois períodos na peculiar leitura de Pedrosa sobre as relações políticas, econômicas e sociais do Brasil e destes com o capitalismo internacional provavelmente nos permita apresentar uma contribuição original de Pedrosa para a história do pensamento político e econômico brasileiro contemporâneo nestes momentos em que nos debatemos com avanços autoritários. Buscamos nessa mesma perspectiva analisar as possíveis continuidades, rupturas e a evolução do aparato conceitual de análise utilizado por Pedrosa para abordar esses dois momentos específicos de sua atividade política e da história do país.

O conceito de bonapartismo provavelmente tenha sido a ferramenta constante e central nas análises que realiza dos dois períodos, e que remete à sua compreensão da permanente oscilação do regime político de um estado dependente como o brasileiro. Isso teria permitido muito provavelmente a Pedrosa absorver e mirar criticamente o chamado "ciclo nacional populista desenvolvimentista" do pós Segunda Guerra não como uma fase específica e de ruptura na história política e econômica nacional, mas muito mais como uma quase previsível oscilação de um mesmo regime político de características comuns. E seria preciso acrescentar nessa abordagem as dimensões combinadas, interna e externa, das estruturas econômicas deste regime bonapartista, bem como suas expressões políticas caracteristicamente oscilantes: ora democráticas e ora autoritário-ditatoriais. Mário Pedrosa incorpora como seu método de análise, de maneira contínua e dialética, o exame dos deslocamentos do regime político nacional e seu específico lastro econômico, seus ajustes internos que combinam não só à luta de classes, mas às lutas fracionais no interior da burguesia. As oscilações do regime bonapartista são igualmente compreendidas sob o impacto das pressões do mercado mundial e do seu núcleo estadunidense.

Pedrosa se utiliza também de outro conceito fundamental, o de desenvolvimento desigual e combinado, como ferramenta articuladora para a análise das oscilações internas do regime político na ação política nacional e suas conexões específicas com o 
capitalismo nacional e internacional. Seus primeiros textos mais densos escritos na década de 1930 possuem esse fio condutor e interpretativo. E podemos observar que os seus principais textos e livros já no período da ditadura de 1964, em particular $A$ Opção Brasileira e A Opção Imperialista, igualmente se confrontam e se combinam dialeticamente como resultado destas ferramentas, categorias e conceitos manejados por Pedrosa. A expressão desse fenômeno do desenvolvimento desigual é expresso, portanto, pela leitura de Pedrosa da própria história política e econômica, a luta de classes e os seus resultados na dimensão da luta política cotidiana do país. Compreender o que se passava no Brasil desde $1^{\circ}$ de abril de 1964 e como se chegara a esta situação implicava combinar e compreender esse conjunto complexo e combinado dialeticamente: os deslocamentos do regime bonapartista desde a década de 1930 e suas oscilações autoritárias e democráticopopulares, mas também o capitalismo nacional com suas dinâmicas internas e com o mercado mundial pautados por uma dinâmica desigual e combinada. Buscaremos, nesse sentido, não tratar diretamente do momento específico da história política nacional entre 1945 e 1964, que poderia ser vista como uma oscilação democrática do regime, mas dos seus dois extremos autoritários.

\section{O dirigente antifascista ${ }^{2}$}

Como jovem militante socialista liderou na década de 1930, em São Paulo, a resistência antifascista em atos de rua e em inúmeros textos que redigiu contra o avanço fascista e os governos autoritários que se consolidavam. O Brasil daquela época era bem diferente do que seria em 1964, a burguesia estava dividida depois do movimento de 1930 e o regime político seguia instável. A crise econômica depois de 1929 se aprofundava e mobilizações sociais de trabalhadores cresciam. Um partido - a Ação Integralista Brasileira - inspirado nos movimentos fascistas europeus avançava e, ainda que caricatural em seus gestos e medíocre em seus manifestos e propostas, ameaçava

\footnotetext{
${ }^{2}$ Alguns parágrafos desta seção foram publicados em A Terra é Redonda sob o título "Mário Pedrosa, antifascista": ANDRADE, Everaldo de Oliveira. Mário Pedrosa, antifascista. A Terra É Redonda, São Paulo, 12 jun. 2020. Disponível em: <https://aterraeredonda.com.br/mario-pedrosa-antifascista >. Acesso em: 31 jan. 2021.
} 
organizações sindicais e partidos operários, ganhava simpatias de setores como policiais, militares, políticos e das camadas médias e pequeno-burguesas.

O jovem Mário Pedrosa, então com 33 anos, atuava como dirigente da Liga Comunista Internacionalista (LCI), organização que integrava a chamada Oposição de Esquerda Internacional liderada por Leon Trotsky e que aspirava nesse momento reformar a III In Internacional stalinizada. A Oposição havia decidido e aplicava em todos os países uma orientação pela mais ampla unidade das organizações operárias para barrar o avanço do fascismo. No Brasil, Mário Pedrosa, à frente de um aguerrido grupo de militantes da LCI, lançou um chamado a todas as organizações em São Paulo para que se unissem e formassem uma frente única para enfrentar as primeiras ações dos bandos integralistas. Nessa mesma época Pedrosa também está editando no Brasil o livro clássico de Leon Trotsky em que analisa a ascensão do nazismo Revolução e contrarrevolução na Alemanha, que ele traduz e apresenta (TROTSKY, 1979).

A frente única antifascista (FUA) é lançada em um comício realizado em 10 de junho de 1933 em São Paulo, organizado em memória do operário italiano Giacomo Matteotti assassinado pelo regime de Mussolini. Mais de 500 pessoas estiveram presentes. No dia 14 de julho, também para celebrar a data da queda da Bastilha e início da revolução francesa, um novo ato político inaugurou oficialmente a frente única antifascista em São Paulo. A frente agrupava grupos e jornais anarquistas, socialistas, trotskistas, militantes sindicalistas, imigrantes e até comunistas stalinistas de base, apesar do veto de sua direção. A polícia depois prendeu Mário Pedrosa e vários militantes, logo soltos. Os choques com os bandos fascistas passaram a se multiplicar na capital paulista. No dia 14 de novembro de 1933 uma manifestação da FUA que se realizava em um salão da Avenida Celso Garcia no bairro operário do Brás foi atacada por dezenas de integralistas que forçaram a entrada no local. A polícia chegou mas apenas assistiu o ataque dos fascistas para em seguida também atacar os participantes quando saíam para suas casas. $O$ movimento antifascista não se intimidou e seguiu em atividades nas ruas. No dia 25 de janeiro de 1934 convocou uma grande manifestação pública no Largo da Concórdia, que foi previamente tomado pelas forças de repressão da polícia para intimidar o movimento. Mário Pedrosa foi um dos poucos oradores que conseguiu discursar na manifestação, em 
seguida atacada e dispersada com cavalos da Força Pública, a equivalente na época à atual polícia militar.

O núcleo militante que animava a frente era composto pelos militantes da LCI liderados por Mário Pedrosa. Eles haviam decidido, para ajudar na constituição e consolidação da campanha antifascista, fundar um jornal de massas em 1933 - O Homem Livre. As páginas deste periódico, que circulou na capital paulista entre 1933 e 1934 são das mais interessantes testemunhas históricas da tenacidade e coragem do movimento antifascista, além de revelar também os embates e dificuldades da luta cotidiana. O jornal buscava aproximar representantes de diferentes organizações, mobilizar as camadas trabalhadoras da cidade, informar e denunciar a barbárie do fascismo na Europa e combater os fascistas no Brasil. Mário Pedrosa escreveu em pelo menos 12 dos 22 números publicados. A maior parte dos artigos eram assinados apenas por pseudônimos para evitar represálias. O jornal conseguiu sobreviver heroicamente, acompanhando e relatando as iniciativas da FUA. Seu último número foi publicado em fevereiro de 1934 cumprindo seu principal papel de consolidar o amplo movimento da frente única.

Mário Pedrosa escreveu artigos principalmente sobre temáticas da luta antifascista. Mas também colaborou com temas culturais como uma interessante resenha sobre o filme recém-lançado Scarface de 1933 em que ele aproveita para comparar a prática dos gangsteres de Chicago com àquelas das burguesias de todos o mundo; uma resenha do livro História do Brasil do poeta Murilo Mendes em que ele destaca a importância dos poemas sobre Canudos, Palmares e a revolta da Chibata; e uma longa resenha publicada ao longo de quatro números sobre a exposição em São Paulo de pinturas da artista alemã Khäte Kollwitz e que é praticamente sua estreia como futuro e brilhante crítico de arte.

Entre os vários artigos políticos, preocupados centralmente em analisar o avanço do nazismo, aquele de maior importância pela lucidez de análise e das perspectivas que oferece, talvez seja O Nacional socialismo e a crise econômica: lições da derrota do proletariado alemão no mês de setembro de 1933 (O Homem Livre, 1933, 13). Nesse texto Mário Pedrosa faz um balanço da crise econômica alemã sob o governo nazista, que se iniciava com a subida de Hitler como chanceler em 30 de janeiro de 1933. Se seguem nos meses seguintes medidas de fechamento de partidos, sindicatos e demais instituições 
democráticas, o que abria caminho para a ditadura nazista. Ele cita as declarações apaziguadoras tanto de socialistas como de comunistas, estes afirmando publicamente que a crise e a miséria dos trabalhadores e da pequena burguesia alemã fariam em breve cair o nazismo. Para Mário Pedrosa esta análise era completamente superficial e ignorava a derrota sofrida pelos trabalhadores alemães. Indignado, ele escreve:

O otimismo dessas afirmações são fanfarrônicas, põem de lado completamente uma coisa: o papel do partido proletário [...] não notam que, enquanto isso, o fascismo venceu na Alemanha e destruiu as organizações operárias, inclusive os seus partidos políticos, os seus clubes esportivos e, as suas bibliotecas, os seus sindicatos, as suas cooperativas, os seus comitês de fábrica, etc. De que maneira a indignação ou a revolta das massas tomará a forma de uma resistência positiva sem ser por meio de suas organizações de classe? Como pode ser organizada a resistência contra o fascismo sem ser por meio do partido de classe? (O Homem Livre, 1933, 13).

No mês seguinte, em outubro de 1933, um novo artigo de Pedrosa descreve as negociações e tentativas das potências imperialistas para conter o rearmamento de Hitler, que buscava nesse momento convencer as potências capitalistas de que o seu objetivo principal era a destruição da União Soviética para completar a obra de destruição já avançada do movimento operário alemão. Escreve Pedrosa:

Para consolidar as suas posições dentro do país, viu-se o fascismo obrigado nos primeiros tempos a apresentar-se com uma extrema prudência no lado de fora. Foi mesmo preciso despir-se de seu caráter belicoso e chauvinista, anti-francês, e dar as potências imperialistas outras garantias de suas boas intenções de vizinhança. [...] Mas eram estas apenas as premissas políticas para a ação ulterior da burguesia imperialista da Alemanha. O capitalismo alemão, precisando de novos mercados e novo campo de escoamento à sua produção, exige agora a execução da outra etapa da "revolução" nazista. [...] Hitler precisa armar-se para lançar definitivamente a sua candidatura a chefe de uma cruzada capitalista antissoviética (O Homem Livre, 1933, 17).

Mas Mário Pedrosa também critica a posição da União Soviética em subestimar a capacidade do movimento operário e apostar em um caminho de concessões e acordos com os países capitalistas:

Presos à miragem do socialismo nacional, os dirigentes soviéticos, sem fé nas forças do proletariado internacional, preferiram recorrer aos métodos das negociações diplomáticas, das combinações com os governos capitalistas, das ilusões do pacifismo, à procura de garantia de paz e de segurança pelos acordos 
e tratados internacionais, os pactos de não-agressão e de amizade, os conchavos "desarmamentistas", e enredar-se na malha das Intrigas diplomáticas imperialistas (O Homem Livre, 1933, 17).

\title{
E prossegue:
}

\begin{abstract}
A sorte do Estado soviético sempre esteve indissoluvelmente ligada à sorte das massas oprimidas pelos imperialistas. A política da diplomacia soviética separou porém, os seus interesses imediatos dos interesses das massas proletárias no exterior. [...] É hora do proletariado reafirmar o seu internacionalismo ativo para impor ao mundo capitalista a sua solução, isto é, a civilização radiosa que traz no seu seio. Aos povos europeus às vésperas de serem novamente assassinados, é preciso que a voz poderosa do internacionalismo proletário se faça ouvir ( $O$ Homem Livre, 1933, 17).
\end{abstract}

Mário Pedrosa não era militante de escritório ou só de textos publicados. Nos meses que cobrem o ano de 1933 e 1934 esteve em inúmeras atividades nas ruas, envolvido com a organização e as ações antifascistas na capital. No 1o de Maio de 1934 a FUA conseguiu reunir mais de três mil pessoas em frente ao palácio das Indústrias no Parque D. Pedro. Mário Pedrosa discursou em nome da Liga Comunista e chamou o Departamento Estadual do Trabalho de "bordel do trabalho", defendendo a unidade dos trabalhadores para enfrentar o fascismo e a formação de milícias operárias para defesa e enfrentamento às agressões ao movimento (KAREPOVS, 2017, p. 62). Mas a maior e histórica manifestação antifascista que marcou a história da FUA foi, na verdade, uma contramanifestação articulada para impedir uma grande celebração integralista que se preparava. O enfrentamento ocorreu no dia 7 de outubro de 1934 em plena praça da Sé no centro da capital paulista. Mário Pedrosa atuou como dirigente da FUA e da LCI na preparação da contramanifestação, conseguindo até a adesão dos stalinistas. A ação consistia em impedir de todas as formas que os integralistas, que organizavam até caravanas de cidades do interior e de outros estados, comemorassem o seu segundo aniversário em praça pública. O livro A revoada dos galinhas verdes de Fúlvio Abramo, narra e documenta todos os detalhes desta luta memorável (ABRAMO, 2014). De fato, uma batalha campal e um tiroteio de horas impediu que os fascistas brasileiros tomassem as ruas e ocupassem a praça da Sé. Entre os feridos, Mário Pedrosa levou um tiro durante a luta. Quatro policiais e um jovem militante comunista morreram. 
Em texto redigido em 1937, já expressando um balanço mais maduro desses acontecimentos, Pedrosa procurou oferecer uma análise da cor local do fascismo brasileiro. Apesar das suas arruaças e discursos bravateiros, o fascismo brasileiro era limitado e dependente de outros setores para prosperar rumo ao poder:

\begin{abstract}
O fascismo colonial é forçado a procurar o apoio do quê carece infiltrando-se no aparelho de estado, por entre militares e funcionários, de obter por cima os seus objetivos, isto é, o poder.... uma política dúplice, de meia cara, de cambalachos e conspiratas, com prejuízo da sua combatividade e do caráter plebeu necessários a sugestionar às massas, isso porque não é de se prever uma vitória (que não será muito fácil) do fascismo no Brasil, pelas vias clássicas europeias [...]. Antes, essa vitória poderia vir mais provavelmente através de golpes de estado bruscos, desfechadas em colaboração com uma parte das Forças Armadas, encabeçados por generais salvadores, como na Espanha, na Polônia, etc, [...]. Sem a cooperação de generais reacionários, o caminho para o poder estará bloqueado ao fascismo... (PEDROSA apud KAREPOVS, 2015, p. 324).
\end{abstract}

O golpe do estado novo liquidou com as pretensões mais imediatas dos fascistas brasileiros. Mas nos chama atenção o destaque que Pedrosa demarca a respeito dos atalhos golpistas e das relações promíscuas entre os bandos fascistas e os setores autoritários militares com os quais seria dependente para buscar acesso ao poder de estado. Se em 1937 esse caminho foi obstado, em 1964 como veremos a frente, o problema se colocou novamente na medida em que o fascismo não seria um fenômeno isolado, mas parte integrante e excepcional - inclusive como ideologia - do funcionamento e manutenção do capitalismo. Embora o integralismo na década de 1960 não possuísse mais a mesma dimensão enquanto movimento fascista organizado, seguiu enquanto ideologia e corrente de opinião capaz de galvanizar setores sociais específicos radicalizados contra o movimento operário. Pedrosa afirma já neste mesmo texto de 1937 sobre as relações do fascismo com o capitalismo como elementos de um mesmo componente químico, que foram posteriormente sistematicamente silenciadas e combatidas pelos liberais como se fossem seres de universos distantes: "pensar que, nos quadros do regime capitalista, o fascismo pode ser destroçado pela raiz, é pura insensatez. Para extirpar o fascismo da face da terra é preciso extirpar com ele o capitalismo (...)”. (PEDROSA apud KAREPOVS, 2015, p. 324).

Voltemos à década de 1930. Havia resistências evidentes e esperadas às ações da FUA vindas não só dos fascistas, mas boicotes mais explícitos de empresários alemães e 
italianos fascistas residentes no Brasil, perseguição policial sistemática. Mas também havia a surpreendente resistência do partido comunista brasileiro (PCB), já quase todo absorvido pelas orientações sectárias da tirania stalinista. O PCB chegou a integrar por alguns meses a FUA mas depois saiu, o que mereceu um artigo nada elogioso de Mário Pedrosa, intitulado "Coerência na deserção", aliás o último que ele escreveu no jornal:

\begin{abstract}
Na luta contra o fascismo, na defesa das liberdades democráticas, que hoje só beneficiam os oprimidos em luta pela sua emancipação, não há lugar para os que passivamente acreditam em verdades reveladas, em dogmas dirigidos à custa de falsificação e mentira. Persistir nos erros que levaram à catástrofe alemã não seria agora apenas uma capitulação, mas uma traição deliberada a causa das classes trabalhadoras (O Homem Livre, 1934, 22).
\end{abstract}

As inúmeras atividades da FUA demonstraram ao longo dos anos de 1933 e 1934 uma viva capacidade do movimento operário de então em liderar e garantir até onde foi possível, as mais elementares liberdades democráticas então cada vez mais ameaçadas. Nos anos seguintes o Brasil seria sacudido por novos choques políticos. Os stalinistas brasileiros que boicotaram a FUA e meses depois foram orientados por Stálin a buscarem uma aliança comum com a burguesia - sem, contudo, romperem completamente com a política ultra-esquerdista do $3^{\underline{0}}$ período que desembocaria na aventura militar comunista de 1935. Essa serviu como excelente pretexto para uma ampla repressão ao conjunto das organizações dos trabalhadores, facilitando o caminho para a brutal ditadura varguista. Pedrosa criticou a Aliança Nacional Libertadora (ANL), de fato uma ampla frente democrática que buscava submeter o proletariado à burguesia brasileira em nome da luta contra o fascismo. A ANL nunca teve uma existência própria e foi constituída a partir de um acordo entre os dirigentes do Partido Comunista, alguns setores militares e políticos pequeno-burgueses. Sua base era constituída sobretudo por militantes de vanguarda, simpatizantes do comunismo e entusiastas da União Soviética (PEDROSA apud KAREPOVS, 2015, p. 286).

\title{
Entre o fascismo e o bonapartismo
}


A nova composição do estado brasileiro que nascia do movimento de 1930 e que seguia instável nos anos seguintes em que a FUA atuou refletia de forma mais estrutural uma reconfiguração em andamento do capitalismo no país e das forças das diferentes frações da burguesia. Ao mesmo tempo em que se desenvolvia uma tendência à centralização econômica, havia obstáculos e tradições locais de caráter federativo a serem superadas e que se expressavam na crise política e, por consequência, nas dificuldades de articulação e representação política nacional da burguesia brasileira. Esse descompasso entre as necessidades concretas das frações burguesas mais avançadas ou conectadas com os centros industriais internacionais e o regime político ainda atrelado a uma articulação excessivamente federativa é destacado por Pedrosa em seu texto de 1937 como plataforma da qual se projetam as tendências centralistas e autoritárias que iam além do fenômeno fascista:

\footnotetext{
A economia nacional exprimiu-se, pela primeira vez, sobre uma forma política bastante nítida, em outubro de 1930, com a revolta de suas forças produtivas contra a hegemonia da monocultura cafeeira. A tendência centralizadora tomou, então, um grande impulso, transformando-se mesmo numa corrente política que por algum tempo chegou a dar as cartas na política federal. [...] A tendência centralizadora é quase, nas condições atuais, uma imposição econômica (PEDROSA apud KAREPOVS, 2015, p. 302).
}

Dessa forma, ao contrário do que talvez se poderia supor, a possibilidade de uma centralização autoritária do estado em acordo com as necessidades do capitalismo revelava as fragilidades da burguesia nacional como classe, tanto em sua coesão interna como na capacidade de se impor sobre as massas populares em um período de crise econômica aguda. A pressão e domínio do mercado mundial sobre a economia do país e a mobilização independente dos trabalhadores tornavam-se os móveis centrais da dinâmica de funcionamento do regime político no país, como observava Pedrosa: "A sorte dos regimes políticos burgueses nos países dependentes está intimamente ligada ao desenvolvimento desigual de suas economias, do grau de pressão imperialista e a fraqueza congênita de seu estado." (PEDROSA apud KAREPOVS, 2015, p. 321). Tratava-se assim de duas ordens de fatores que ameaçavam e empurravam para uma solução autoritária o regime: as necessidades econômicas e as fragilidades políticas da classe dominante. A tendência que se verificava era de um estado com instituições cada vez mais 
centralizadas para fazer frente aos problemas e necessidades do capitalismo, ao mesmo tempo que se buscava impedir que as camadas populares avançassem, ainda que pela via da democracia, em seus direitos e na sua organização autônoma e independente (PEDROSA apud KAREPOVS, 2015, p. 312).

A democracia não era o terreno mais favorável neste momento para que a burguesia brasileira pudesse consolidar um novo regime político. Como lembra aqui Mário Pedrosa, ainda que a democracia formal ou parlamentar não garantisse os plenos direitos aos trabalhadores, sua vigência favorecia a sua organização e politização. As possibilidades de conquistas sociais e econômicas não correspondiam as concessões da burguesia, mas às ações das camadas trabalhadoras: "a conquista do sufrágio universal custou às massas anos e anos de luta e sacrifícios, inclusive revoluções políticas" (PEDROSA apud KAREPOVS, 2015, p. 317). O terreno da democracia, com todas as suas limitações para a organização dos trabalhadores, permitiria que estes tivessem espaços de articulação, politização e defesa de seus direitos:

\begin{abstract}
Somente o proletariado e as camadas mais proletarizados da pequena burguesia são diretamente interessados no vicejamento de um autêntico regime democrático. É o proletariado a única classe que precisa tanto de liberdade quanto de pão, pois sem aquela este não está garantido [...]. Não sem motivo Pedrosa destaca que "nos países como Brasil, a democracia tem um caráter precário, devendo ser a cada momento reconquistada (PEDROSA apud KAREPOVS, 2015, p. 321-322).
\end{abstract}

As iniciativas da classe operária como a FUA foram assim fatores de instabilidade para o projeto centralizador em curso e não poderiam ser menosprezadas, inclusive por oferecerem e favorecerem uma perspectiva democrática para as amplas massas populares ao avanço e consolidação de um possível regime autoritário e centralizador.

Se o regime político pós 1930 não caminhava para a democracia, o integralismo buscava cumprir vários papéis entre os quais ocupar um polo de centralização nesse período de instabilidade do regime. A ameaça fascista nesse momento não era um fenômeno isolado ou extraordinário, mas enlaçado com as próprias tendências e necessidades do capitalismo de centralização do mercado nacional, precisando então contar com uma massa mobilizada a seu serviço em todo o país. As observações de Mário 
Pedrosa refletem a respeito destes vínculos econômicos do fascismo com os interesses diretos dos capitalistas:

Tanto a grande como a pequena burguesia brasileira não têm tradições políticas e muito menos tradições democráticas: ao longo de sua história nunca foram capazes de forjar qualquer coisa de parecido com o verdadeiro partido político de existência nacional e vivendo sem os favores e bafejos oficiais. [...] Apareceu afinal, pela primeira vez, um tal partido de âmbito nacional. E, coincidência decisiva, esse partido foi o integralismo, isto é, um fascismo nacional, montado e pago pelos capitalistas para esmagar o proletariado brasileiro e sua futura revolução (PEDROSA apud KAREPOVS, 2015, p. 285-286).

Ainda que o integralismo se oferecesse como a máquina política dos capitalistas para se colocar na linha de frente de ataque ao movimento operário, não era a única via com que contavam as diferentes frações da burguesia para centralizar o regime político. Outra possibilidade abordada por Pedrosa para o desenlace da crise de representação política da classe dominante, em texto de 1936, desenvolve a hipótese de uma via bonapartista, que seria uma saída política a ser construída "por cima" das classes sociais e igualmente centralizadora:

\begin{abstract}
Sob a aparência de uma situação muito sólida, Getúlio sente-se fraco e inquietase com futuro [...]. É evidente que por mais que a grande burguesia nacional, seguindo à risca as ordens dos patrões imperialistas, queira perpetuar o estado atual de repressão, transformado em "forma normal" de governo a atual ditadura policial burocrática, é impossível tornar estável e permanente esse "sistema" governamental... falta um "árbitro" nacional elevado acima dos partidos, com autoridade bastante para realizar a readaptação. Esse 'árbitro' seria o resultado da neutralização de forças dos dois campos antagônicos irredutíveis - o movimento de direita, burguês fascista, e o movimento de esquerda, democrático proletário [...] (KAREPOVS, 2017, p. 260).
\end{abstract}

Mário Pedrosa não desprezara a capacidade que o getulismo teve em deter as possibilidades de avanço da consciência de classe dos trabalhadores e escreveu trinta anos depois: "Getúlio Vargas, a primeira investidura de bonapartismo no país, teve de exercer o poder não para impor uma classe sobre as outras, mas, ao contrário, para conciliá-las" (PEDROSA, 1966a). O regime bonapartista inaugurado e consolidado por Vargas após o golpe de 1937 tornou-se afinal a resolução da crise. Mais do que isso, um elo de ligação e continuidade da dominação da burguesia permitindo analisar e comparar os dois 
períodos autoritários. Afinal, menos de vinte anos separavam o nascente governo militar de 1964 da última ditadura, a de Getúlio Vargas.

\section{Fascismo dependente, desigual e combinado}

Em 1938 o ainda jovem revolucionário Mário Pedrosa foi o único representante latino-americano na conferência de fundação da $4^{\underline{a}}$ Internacional sob a liderança de Leon Trotsky. Naquele momento o mundo estava a beira do precipício da Segunda Guerra mundial e no Brasil o país afundava na brutalidade da ditadura Vargas. Pedrosa vive um conturbado exílio entre 1938 e 1945 no qual circula entre França e Estados Unidos com uma tentativa frustrada de volta ao Brasil. Nesse período também rompe com Trotsky e a $4^{-}$Internacional33. Só retorna em 1945 para seguir atuando através do jornal Vanguarda Socialista e depois no partido socialista. No período entre sua volta ao Brasil e 1964 Pedrosa atua em inúmeras frentes: funda o jornal Vanguarda Socialista que é publicado até 1947 e depois ingressa no PSB (partido socialista brasileiro) com um grupo de militantes. Na área profissional ganhará destaque sua atuação como crítico de arte e articulista nos principais jornais do país com contribuições sobre crítica de arte e política.

Com o golpe militar de abril de 1964 Mário Pedrosa procurou responder publicando sua obra central de interpretação do Brasil, dividida em dois livros: Opção Brasileira e Opção Imperialista. Livros de combate, que guardam ao mesmo tempo o ritmo jornalístico e a densidade analítica de largo fôlego, refletem o calor da intervenção política imediata e cotidiana entrelaçada com a perspectiva estratégica das transformações radicais. Ele sai candidato a deputado federal em 1966 pelo então MDB e utiliza a obra como um dos instrumentos de propaganda. No ano de 1968 quando a ditadura militar brasileira preparava um novo assalto autoritário contra a sociedade brasileira, ainda ocorriam passeatas e jornais, ainda que intimidados, publicavam apelos e manifestos democráticos. Nesse ano o velho Mário estava novamente nas ruas. A grande passeata dos Cem Mil de 1968 contra a repressão no Rio de Janeiro tornou-se um

\footnotetext{
${ }^{3}$ Sobre o período exílio de Pedrosa nos EUA ver a recente pesquisa de Marcelo Ribeiro Vasconcelos: VASCONCELOS, Marcelo Ribeiro. O exílio de Mário Pedrosa nos Estados Unidos e os New York Intellectuals: abstracionismo na barbárie. Tese - Campinas: Universidade Estadual de Campinas, 2018.
} 
acontecimento nacional e na primeira fila dos encabeçadores vemos o mesmo Pedrosa em franco o combate político. E no final da sua vida, no ano de 1980, ele inicia a lista dos primeiros filiados ao PT depois de insistir durante anos para que os dirigentes operários do $\mathrm{ABC}$ tomassem a frente a construção de um amplo e democrático partido operário de massas.

O alvo imediato dos seus livros publicados em 1966 era a ditadura iniciada com o golpe militar de abril de 1964, seu significado mais profundo não apenas diante da história recente do país, mas também em relação à trajetória mais abrangente das tensões da conjuntura internacional. Da ampla obra de mais de 1.000 páginas certamente ganha destaque o tema das raízes sociais e econômicas do autoritarismo da burguesia brasileira. O golpe de 1964 demonstrava o entrelaçamento entre a história mais profunda da formação do capitalismo no país e uma combinação mais recente das forças golpistas entre as camadas médias com seus traços fascistizantes, as oligarquias rurais e as influências externas dos EUA. A direita conservadora brasileira possuía traços e ações de caráter autoritários vindos do escravismo entranhadas em sua gênese social e que remetiam ainda à década de 1930 quando o fenômeno fascista tomou corpo no movimento integralista e não desapareceu. Mário Pedrosa não se utiliza do conceito de fascismo para caracterizar a ditadura - se reporta aqui ao conceito de bonapartismo militar como veremos - mas descreve como práticas de tipo fascistas as ações dos setores radicalizados e anti-operários que se mobilizam entre a pequena-burguesia.

Pedrosa descreve em diversas ocasiões as cenas e mobilizações de traços fascistizantes de fanáticos das camadas médias pequeno-burguesas, que saíam às ruas para dar sustentação ao golpe militar, além de registrar o lastro rural do autoritarismo fascista. O antigo fascismo brasileiro da década de 1930, e que ele chamara de "fascismo colonial”, continuava sendo parte fundamental do arsenal da burguesia brasileira principalmente quando se tratava de inviabilizar a frágil democracia. Em 1937 Pedrosa já chamara a atenção para outro aspecto da adesão de setores da pequena-burguesia à ideologia fascista e autoritária: às fragilidades do movimento operário em atraí-las:

A pequena burguesia, por sua vez, espiritualmente dominada e conduzida pela grande burguesia, cedo também tende a perder o encanto pela democracia, sobretudo porque o peso social e a influência política do proletariado não tem 
nesses países a preponderância que tem nos países de grande indústria. Facilmente explorável pelas piores forças reacionárias, a pequena- burguesia tende a fazer recair parte da culpa pelos males de quê padece sobre as costas do proletariado, cuja ação e cujas lutas ela se inclina a condenar como "prematuras", condenando a "impaciência" do proletariado. Os pequeno-burgueses inocentam a própria burguesia nacional (apud KAREPOVS, 2017, p. 322).

Trinta anos depois seu diagnóstico manteria a mesma avaliação? A ditadura varguista e depois o período democrático bastardo entre 1945 e 1964 que nasceu no pósguerra, seguiam se transmutando ainda como parte de um mesmo regime do capitalismo no país. Dessa forma, se se ampliaram as mobilizações populares e nacionalistas, ocorriam ao mesmo tempo que surgia um movimento operário mais robusto. Porém, era sob um controle estatal e da burocracia sindical do trabalhismo como não se verificava antes. E essa é uma particularidade importante do bonapartismo nesse período, quando gira para mobilizar as massas em torno do nacionalismo, porém sob controle e sem plena independência. Essa característica tutelada do movimento operário organizado em torno dos sindicatos e a ausência de um forte partido operário que atuasse com total autonomia do trabalhismo varguista tem consequências, pois afeta os movimentos oscilantes das camadas médias pequeno-burguesas e facilita adesões à ideologia fascista, que se combina de maneira desigual e subordinada ao regime bonapartista. É o que Mário Pedrosa identificava em 1966 na polarização social que deslocara e separava mais radicalmente as camadas médias atraídas ao discurso de conotações fascistas dos setores de trabalhadores: "A demonstração vinha evidenciar um fenômeno extremamente importante na avaliação da situação: a separação nítida entre a massa das classes médias, sobretudo as camadas menos proletarizadas e a massa proletarizada e plebeia, incluindo nela a maioria dos assalariados" (PEDROSA, 1966, p. 134). Em outro momento ele retoma o mesmo diagnóstico do fenômeno social e político que radicalizava e canalizava camadas pequeno-burguesas fanatizadas para as ruas e contra o movimento operário e popular. Uma intensa propaganda política havia mobilizado estes setores a se afastarem de perspectivas, ainda que reformistas e progressistas, nascidas do movimento operário:

Foram as camadas mais radicais da classe média, de a muito submetidas a um processo de hipnose, que saíram primeiro à rua, para protestar, para a baderna, e de imediato essas formas de luta tomaram a feição mais primária e fanática. [...] Eis aí, bem traçado, o quadro em que seria travada uma luta "política" entre 
partidários da mudança social e partidários da intocabilidade social. A tônica da luta nada mais tem de política, é puro fanatismo religioso, ódio irracional ao progresso, medo a tudo o que pode conter de obscuro o vocábulo 'comunismo'. (PEDROSA, 1966, p. 128)

Esse movimento social evidentemente não é isolado. Em 1966 o imaginário fascista da pequena-burguesia conservadora das cidades está presente ao lado do jaguncismo rural como expressão de um mesmo fenômeno político. Pedrosa relaciona esse movimento de características fascistas e urbano que apoiava o golpe com suas articulações rurais. Os grandes proprietários mobilizavam apoios e grupos armados irregulares para o golpe militar: "os quadros da linha de frente da contrarrevolução no meio urbano vinham das classes médias e pequeno-burguesas; enquanto que no interior eram formados pelos jagunços armados, a soldo dos grandes proprietários" (PEDROSA, 1966, p. 130). Esse é um lastro rural em que os grandes proprietários rurais ainda mantém e lhes permite manipular massas rurais a seu favor como clientelas submetidas. $\mathrm{O}$ jaguncismo tem aí um papel de milícia sobre o campesinato, ao que se soma o fato do país ainda possuir massas urbanas que crescem mas ainda ligadas por muitos fios à vida no campo.

\section{O totalitarismo estrutural dos EUA no golpe de 1964}

Grande parte das observações e posicionamentos publicados por Pedrosa em 1966 a respeito da intervenção dos EUA no golpe são hoje amplamente reconhecidos, mas estamos tratando de uma obra que foi publicada apenas dois anos após o golpe. Mário Pedrosa não tinha nenhuma ilusão nas veleidades democráticas da burguesia brasileira e muito menos nas intenções supostamente progressistas dos Estados Unidos em relação à América Latina. Muitos dos documentos que hoje comprovam as afirmações de Pedrosa só se tornaram públicos décadas depois. Ele, por exemplo, se refere à ofensiva autoritária dos Estados Unidos como o principal ponto de apoio externo da ditadura que se construía, com uma estrutura de propaganda externa golpista anterior a abril de 1964 na qual os golpistas se apoiavam para insuflar a ideologia fascista: "a classe média brasileira foi submetida a um processo de hipnose que a arrastava a um anticomunismo irracional e fanatizado. Era a chamada guerra psicossocial desencadeada aqui por setores estratégicos 
das Forças Armadas e, certamente, por instrutores do Pentágono para cá mandados” (PEDROSA, 1966, p. 120). Não haveria atualmente nada de novo em relação a esta afirmação a não ser pelo fato de que Pedrosa buscou demonstrar que havia também uma linha de continuidade da política externa dos EUA com os regimes fascistas da década de 1930. Há aqui originalidade em sua abordagem. Pedrosa chama isso de "herança totalitária” e busca contextualizá-la no quadro mundial de então, marcado pela chamada "guerra fria" com a URSS.

De fato, após 1961 havia se radicalizado a política dos EUA para América Latina. Mas Pedrosa vai além de um aspecto mais estudado e conhecido relacionado às repercussões da revolução cubana de 1959 na política externa dos EUA. Segundo ele, a articulação com a ditadura brasileira não seria apenas uma virada tática e menos ainda de alcance limitadamente continental. Os antigos convênios comerciais de pós-guerra para compra de produtos que haviam se tornado instrumentos da guerra fria, agora eram insuficientes, se iniciava outra conjuntura com novas exigências de fortalecimento do aparato de Estado em disputa com a União Soviética. Esses novos dispositivos contrariavam as convicções, discursos e ideologias políticas e econômicas liberais e supostamente democráticas (PEDROSA, 1966, p. 199). Explicitava-se uma concepção totalitária mais profunda dos EUA e que se relacionava ao coração de sua economia capitalista em crise. Mário Pedrosa destaca que toda a estruturação do complexo econômico-militar mundial dos Estados Unidos, sua amplitude imperial, de controle e articulação de todos os aspectos da economia, da política e da cultura teriam sido gestados como "reformas contrarrevolucionárias" desde a década de 1930:

\footnotetext{
O capitalismo liberal, impotente para vencer a depressão e por em marcha o mecanismo produtivo econômico mundial, cedeu lugar para regimes transitórios e totalitários, cujo obscurantismo político, moral e cultural revelava profundo retrocesso da própria civilização ocidental. O terrível paradoxo foi que, no plano econômico e financeiro, aqueles regimes quebraram várias ortodoxias intocáveis do capitalismo clássico decadente. Na época atual, provém, em grande parte deste paradoxo (PEDROSA, 1966, p. 271).
}

Para Mário Pedrosa aqui está o ponto de intersecção do que ele conceitua como totalitarismos nazistas e estadunidenses, com repercussões na conjuntura brasileira. Havia uma linha de continuidade que se prolongava submersa por uma suposta guerra 
fria: "A luta do ocidente democrático contra o oriente comunista é uma luta de dragões de fábula para enganar os povos" (PEDROSA, 1966b, p. 234). E essas características ganhavam impulso e densidade com a plena consolidação do poder imperial dos Estados Unidos. E mesmo sobre o velho continente estava agora submetido: "A Europa não tem escolha entre ser vassala política, social e economicamente subsidiária dos EUA ou um sistema autônomo na base de uma economia superior, suscetível de ser a ponte entre a economia capitalista ainda privativa americana e a economia pública socialista da Rússia e aliados" (PEDROSA, 1966b, p. 123). A retórica democrática e anticomunista encobriria tão somente a permanência do autoritarismo mais profundo e sofisticado dos Estados Unidos. Não se trata aqui portanto, de uma virada tática, mas do aprofundamento de uma orientação estratégica anterior de funcionamento do sistema capitalista, cada vez mais centralizado e concentrado nas mãos do estado. A ideologia liberal democrática e anticomunista encobria uma intervenção estatal autoritária, forjada como dispositivo contrarrevolucionário de um estado total de concepção fascista com o qual a nova ditadura brasileira vinha se alinhar.

\section{Fascismo e bonapartismo militar 1964}

Se em 1937 Pedrosa assinalava a fragilidade do próprio fascismo brasileiro, um movimento de tipo colonial e tributário das benesses e relações com o estado para sobreviver - oferecendo afinal o caminho para a ditadura varguista - agora na análise de 1964 em diante é o próprio bonapartismo que ganha particularidades incorporando traços mais característicos dos fenômenos fascistas do Brasil. Ainda que haja um movimento de características fascistas mobilizado como já abordamos, é mais uma vez o regime bonapartista que dirige o centro dos dispositivos de controle do estado, como na ditadura que se segue. Podemos acompanhar Pedrosa examinando essas relações próximas, o gatilho fascista que ajuda a coagir os movimentos operário e camponeses e em geral as massas populares mobilizadas, e que afinal serve para preparar uma solução autoritária por cima.

A peculiaridade nacional da ditadura militar de 1964 estaria expressa no fato de que ela não representaria no poder nenhuma das classes sociais dirigentes em particular, 
mas um tipo peculiar de "bonapartismo militar", algo sui generis ${ }^{4}$. Este seria produto das condições igualmente peculiares como uma combinação das tendências e necessidades mundiais do capitalismo internacional com a realidade nacional das classes dominantes locais, acuadas frente a uma situação revolucionária produzida pela mobilização operária e popular. Como assinalou Pedrosa:

O ódio ideológico aos 'subversivos' e aos 'corruptos' que a ditadura demonstrava era, na verdade, aos 'políticos' brasileiros que o dirigia, os quais mal ou bem serviam àquelas classes no poder. Ela demonstrava assim - e para isso tinha então, provavelmente, a grande maioria da oficialidade dos quartéis - que ia governar 'acima das classes'. [...] E ninguém pode falar pelo exército, porque o exército não é uma classe, nenhum partido mas uma função primordial do estado que é preservar em sua especificidade ótima (PEDROSA, 1966a, p. 184-186).

As relações entre o exército e o bonapartismo ganham assim um componente novo e inusual:

\begin{abstract}
Ora, em geral, todo bonapartismo é poder pessoal, é o poder por suas virtudes, por seus atributos benéficos e maléficos, encarnado em um homem elevado acima de todos, falando em nome da nação, quer dizer, das classes dominantes, no momento de impasse político e social.... Pretendeu-se fazer do exército como um todo, uma entidade bonapartista impessoal (PEDROSA, 1966a, p. 192).
\end{abstract}

Como "bonapartismo militar", a ação da ditadura ocuparia o lugar e o papel do fascismo como movimento organizado de massas. Pedrosa assinala em interessante observação sobre o contraponto em relação ao célebre papel revolucionário que as camadas pequeno-burguesas teriam exercido na aurora das revoluções burguesas:

A ditadura militar terá feito o papel do 'jacobinismo' de marcha à ré que foi o fascismo: o jacobinismo da época das burguesias decadentes, a rampa de descida do curso histórico. Que fez ela de histórico e providencial? Repôs as massas no seu lugar, quebrou neles o ímpeto e o sentimento de autoconfiança que iam adquirindo; reprimiu o balbucio de uma autoconfiança que iam adquirindo no campo. Dissolveu-lhes as organizações de resistência, emasculou-lhes os sindicatos, suprimiu os órgãos centrais de representação, que podiam falar em nome dos interesses coletivos da classe trabalhadora (PEDROSA, 1966a, p. 187).

\footnotetext{
${ }^{4}$ Entre os estudos relativamente recentes sobre a obra de Mário Pedrosa se destacam pelo menos duas pesquisas que abordaram com maior profundidade alguns dos aspectos aqui debatidos: a dissertação de mestrado de Dirlene de Jesus Pereira Rocha (Mário Pedrosa e o estado bonapartista militarizado no Brasil de 1964) defendida em 2004 na UEL e a de Josnei Di Carlo (A interpretação de Mário Pedrosa sobre a Revolução de 1930 e o Golpe de 1964) defendida na UFSCar em 2013.
} 
Agora o seu papel é evidentemente reacionário, de ataque às mobilizações populares. Essa pequena-burguesia nunca se apresentara como movimento fascista orgânico de massas, mas teve papel importante através do exército. E este busca fazer regredir e não fazer avançar o curso progressista da história. São os funcionários orgânicos da ideologia fascista e dos interesses mais amplos da burguesia, articulando não apenas a pequena burguesia tradicional, mas as massas do campo submetidas como clientelas pela repressão do jaguncismo.

Por outro lado, onde estavam as camadas trabalhadoras assediadas de um lado pelo trabalhismo getulista e o colaboracionismo do PCB que reforçam os traços reformistas do movimento operário e, de outro, pela ofensiva dos bandos fascistizantes alinhados aos militares golpistas? Sem uma ação autônoma do movimento operário, a armadilha do bonapartismo poderia novamente fazer um giro a direita como fizera em 1937. Pedrosa resgata essa classe operária que se mobilizava e reagia a partir da situação complexa e concreta que envolvia sua sobrevivência:

Em que pesem as exegeses eruditas dos economistas apologistas do neocapitalismo e o esquecimento do conceito de classe dos teóricos do desenvolvimentismo, a classe operária já sabe que a participação dos salários não lhe é jamais assegurada. Sobre essa primeira constatação se funda o nível inicial de sua consciência de classe. O próprio reformismo do seu comportamento até aqui é a expressão desse nível primário de consciência (PEDROSA, 1966a, p. 289).

Como aqui assinalava, sua consciência política e capacidade de ação política independente como classes foram insuficientes para agrupar um polo social alternativo, revolucionário e anti-fascista capaz de evitar a ditadura que se desenhava.

\section{Conclusões}

Se na década de 1930 já se configurava uma tendência a maior centralização do estado brasileiro, condição imposta ao mesmo tempo pelo capitalismo no Brasil e pelas fragilidades da burguesia nacional tanto no plano interno como internacional, a ditadura iniciada em 1964 poderia ser vista como a renúncia e derrota definitiva dos últimos traços 
de soberania e autonomia de frações organizadas da burguesia nacional. E isso se expressou no fato de que a burguesia perdeu o controle como classe social do regime bonapartista, agora em mãos da corporação militar alinhada ao autoritarismo estadunidense e disposta a aplicar ou se apoiar em práticas fascistas em toda a sua amplitude. Durante os dois períodos ditatoriais em que Mário Pedrosa se debruçou e analisou a dinâmica da luta de classes e das frações da burguesia brasileira em torno do controle do estado brasileiro o fascismo esteve presente como traço marcante através de práticas e da ação de grupos articulados, embora nunca desfrutando de hegemonia entre as forças políticas conservadoras em geral e nas representações políticas da Direita em particular. Se o bonapartismo militar como caracterizado por Mário Pedrosa era resultado do lugar subordinado e dependente da economia brasileira e da sua classe dominante, o fascismo inserido como ideologia política autoritária entre os militares e setores civis a eles vinculados tornou-se um traço perene nas décadas seguintes ao fim da ditadura de 1964. Grande parte das instituições autoritárias foram preservadas após 1988, permitindo a sobrevivência do fascismo como ideologia em setores marginais. $\mathrm{O}$ fascismo agiu sempre como força complementar, de agitação ideológica principalmente entre as camadas da pequena-burguesia mais distanciadas ou claramente hostis às ações do movimento operário e de uma política operária independente. Dessa forma, como em 1937 e 1964, o fascismo é chamado a agir ainda que marginalmente e como discurso, para catalisar e agitar setores conservadores e preparar as condições para um regime claramente autoritário. Em ambos os momentos ditatoriais Mário Pedrosa respondeu reafirmando que a perspectiva da democracia e da liberdade no Brasil estavam nas mãos da sua classe trabalhadora e da capacidade dessa em oferecer uma saída política independente da burguesia brasileira, sendo assim capaz de liderar a nação e assegurar sua democracia. Nesse sentido, Mário Pedrosa segue sendo um pensador atual e capaz de oferecer perspectivas para a superação dos atuais impasses do país.

\section{Referências}

ABRAMO, Fúlvio. A revoada dos galinhas verdes. São Paulo: Veneta, 2014. 
; KAREPOVS, Dainis (orgs.). Na contracorrente da História. São Paulo: Sundermann, 2015 .

ANDRADE, Everaldo de Oliveira. Mário Pedrosa, antifascista. A Terra É Redonda, São Paulo, 12 jun. 2020. Disponível em: <https://aterraeredonda.com.br/mario-pedrosaantifascista>. Acesso em: 31 jan. 2021.

. Mário Pedrosa. In: PERICÁS, Luiz; SECCO, Lincoln. Intérpretes do Brasil: clássicos, rebeldes e renegados, São Paulo: Boitempo, 2014.

DI CARLO, Josnei. A interpretação de Mário Pedrosa sobre a revolução de 1930 e o golpe de 1964. Dissertação - São Carlos: Universidade Federal de São Carlos, 2013.

KAREPOVS, Dainis. Pas de politique Mariô! Mário Pedrosa e a política. São Paulo: Ateliê, 2017.

MARI, Marcelo. Estética e política em Mário Pedrosa (1930-1950). Tese de doutorado, FFLCH - USP, 2006.

MARIE, Jean Jacques. O trotskismo. São Paulo: Perspectiva, 1998.

MARQUES NETO, José Castilho. Solidão revolucionária - Mário Pedrosa e as origens do trotskismo no Brasil. São Paulo: Paz e terra, 1991.

PEDROSA, Mário. A opção brasileira. Rio de Janeiro: Civilização brasileira, 1966.

A opção imperialista. Rio de Janeiro: Civilização brasileira, 1966.

ROCHA, Dirlene de Jesus Pereira. Mário Pedrosa e o estado bonapartista militarizado no Brasil de 1964. Dissertação- Londrina: Universidade Estadual de Londrina, 2004.

TROTSKY, Leon. Revolução e contrarrevolução na Alemanha. São Paulo: Ciências Humanas, 1979.

VASCONCELOS, Marcelo Ribeiro. O exílio de Mário Pedrosa nos Estados Unidos e os New York Intellectuals: abstracionismo na barbárie. Tese - Campinas: Universidade Estadual de Campinas, 2018.

\section{Documentos}

Coleção de jornais O Homem Livre, maio de 1933 a fevereiro de 1934. A coleção completa está disponível na página do CEMAP/CEDEM da Unesp e no endereço https://www.marxists.org/portugues/tematica/jornais/homem/index.htm. 